\title{
ISLAMIC MODERATION MODEL IN MANAGING MOSQUE TO INCREASE PHILANTHROPY FUND AT JOGOKARIYAN MOSQUE YOGYAKARTA
}

\author{
Ahmad Mifdlol Muthohar \\ Institut Agama Islam Negeri (IAIN) Salatiga, Indonesia \\ Email: mifdlol@gmail.com
}

\begin{abstract}
The purpose of this study is to find out Islamic moderation model which is successfully developed by Jogokariyan mosque. The research method used in this study is a qualitative method with descriptive analysis. The research findings show that Islamic moderation approach in managing a mosque gives optimal effect on collecting philanthropy fund. Islamic moderation model developed by Jogokariyan Mosque has characteristics: 1) the leader of the mosque is also the leader of community; 2) Mosque belongs to community and everyone is allowed to use the facilities; 3) philanthropy fund is used not only for ritual aspect but also for social and economic empowerment of community; 4) involving the elements and roles of community to build sense of belonging toward the mosque; 5) developing the icon of Java community such as prayer cap as important icon of the mosque and as the typical merchant to foster economy.
\end{abstract}

Keywords: Jogokariyan, moderation, philanthropy, empowerment.

\begin{abstract}
Abstrak
Tujuan dari penelitian ini adalah untuk mengetahui model moderasi Islam yang berhasil dikembangkan oleh masjid Jogokariyan. Metode penelitian yang digunakan dalam penelitian ini adalah metode kualitatif dengan analisis deskriptif. Temuan penelitian menunjukkan bahwa pendekatan moderasi Islam dalam mengelola masjid memberikan efek optimal pada pengumpulan dana filantropi. Model moderasi Islam yang dikembangkan oleh Masjid Jogokariyan memiliki karakteristik: 1) pemimpin masjid juga merupakan pemimpin masyarakat; 2) Masjid milik masyarakat dan semua orang diizinkan untuk menggunakan fasilitas; 3) dana filantropi digunakan tidak hanya untuk aspek ritual tetapi juga untuk pemberdayaan sosial dan ekonomi masyarakat; 4) melibatkan elemen dan peran masyarakat untuk membangun rasa memiliki terhadap masjid; 5) mengembangkan ikon masyarakat Jawa seperti sajadah sebagai ikon penting masjid dan sebagai pedagang khas untuk menumbuhkan ekonomi.
\end{abstract}

Kata kunci: Jogokariyan, moderasi, filantropi, pemberdayaan.

\section{A. Introduction}

Islamic teaching provides many alternatives for the adherences in the area of philanthropy. The adherences are taught to contribute more to society in various ways such as zakah, infak, sodaqah, hibah, wakaf and etc based on Islamic teaching. One of ways that has been intensively developed is the philanthropy of zakah.

The mandatory to pay zakah focuses on wealth distribution. The distribution is important by Quran as it is stated that the wealth must not circulate only for the rich (QS. Al-Hasyr: 7). For that purpose, according to 
PIRAC (Public Interest Research and Advocacy Centre), the potency of zakah accumulation in Indonesia in the 10 big cities can reach Rp. 9,09 trillion ${ }^{1}$

In further research, the potency of national zakah fund has reached spectacular number. From the national calculation of domestic zakah, the potency

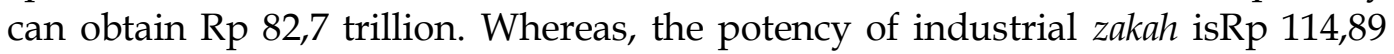
trillion, $\mathrm{Rp} 2,4$ trillion potency of BUMN (state company) zakah, and Rp 17 trillion potency of saving zakah. Thus, the total potency of zakah fund can be Rp 217 trillion, or it is equal to 3,40percent of total PDB (gross domestic product). This research states that the escalation of the percentage potency of zakah toward total PDB becomes an evidence that zakah can be an important instrument to drive national economy, especially to those in need (dhuafa). ${ }^{2}$

That potential number is surely extraordinary amount if it is used for society need equally. Therefore, it generally speaks that official state zakah institution cannot stand alone to withdraw the fund. By the implementation of the Act No 23 Year 2011 on zakah management, it is substantively centralised on the authority of Baznas (National zakahinstitution)3 Meanwhile, society initiative gets a narrow scope because it only can assist Baznas in managing zakah.

In fact, the implementation of zakah Act has not been optimal until to date. In many regions, the development of zakah by LAZ (zakah house) is respectively numerous, and the existence is also various. Several LAZ in national level such as DompetDhuafa, RZI etc have not been fully accepted by local Moslems.

Those zakah houses are non-profit institution to dispense zakah, infaq, and sodaqoh to those who reserve the right (mustahik). The activities involve several related stake holders including contributors, organisers, and recipients. In some cases, the organisers or institutions are not fully familiar for contributors. In this sense, organisers require trust from contributors. Meanwhile, the recipients (mustahik) need to recognise the accountability of funding management (Brown, 2001). Such transparency insists the existence of standardised good governance.

Jogokariyan mosque is located in Yogyakarta, Jogokariyan, Mantrijeron Yogyakarta city. The scope of $D a^{\prime}$ wah covers 4 hamlet (RW 09,10,11 and 12), 18 neigbourhood (RT 30 - 47), with 3970 total population and 887 families. Among $95 \%$ people are Muslims, and the rest are non-Muslims.

This mosque has many advantages that are very well known among Muslims in Indonesia. Arrozy said that significant social changes occur in Jogokariyan mosque, caused by the solidarity of religious revival, which then led to a political-economic movement (Arrozy, 2016).

Jogokariyan Mosque has two types of philanthropic fund management of zakah,infaq and sodaqah. The first management specifically handles zakah and distributes it to 8 groups of recipients as regulated in Islam. Whereas, the second one focuses on managing infaq and sodaqah for various activities in the mosque (Anggoro, 2018).

From the populated data, many posts of syariah economic empowerment have been carried out by the Jogokariyan Mosque. There is an infaq post called GerakanJamaahMandiri, GerakanJamaahShubuh, KampungRamadhanJogokariyan,

1Kompas, 18/4/2017).

2(http://www.zisindosat.com/menggali-potensi-zakat/., date 21 March 2013, retrieved on 25/5/2016).

${ }^{3}$ (http:/ / nasional.tempo.co/read/news/2012/10/24/078437608/Undang-Undang-ZakatDinilai-Diskriminatif, 24/10/2012, retrieved on 18/4/2017). 
Baitul Maal, Persewaan Hotel Masjid JogokariyanandPersewaanAula Islamic Center Masjid Jogokariyan. All of which have high economic values for the syariah economic empowerment of the Islamic community.

The tangible phenomenon of development that seems to be optimal is indispensible from the Islamic moderation model developed by Jogokariyan mosque. Instead of being the largest Muslim population in the world, Indonesia is also a country with a high level of diversity. It can be seen from the variety of cultures, religions, ethnicities and languages, so the society turns into multicultural. In this case, the diversity can be strength as well as threat for the nation. If the diversity is perceived wisely and tactfully by the people with different background, it can be certainly a very powerful pillar of strength. The wisdom and tactfulness are actually the offer from the administrators of Jogokariyan mosque, so the results can be visualised of how Jogokariyan community gets the benefits.

Therefore, this paper tries to discuss Islamic moderation model in managing mosque to increase philanthropy fund in Jogokariyan mosque Yogyakarta.

\section{B. Theoretical Framework \\ 1. Islamic Moderation}

According to Al-Sallabi in Islam \&Khatun 4in defining the word 'moderate', Muslim scientists firstly equated the meaning of the word with an Arabic word 'wasathiyyah'. In general, the word wasathiyyah in Arabic literacy refers to several definitions such as justice, greatness, kindness, and amid. Whereas, Yusuf Qardhawi defines wasathiyyah as a balance that mediates two opposite tips, where there is no a dependent point with supremacy toward another, where both ends do not take more than its appropriate portion and dominate their opponents. 5

Islamic moderation has a multidimensional concept starting from the fulfilment of life's needs, psychology, education and religious aspects that accommodate them in a real life. This is a comprehensive concept with an integrated strategy and a balance of needs for happiness in the world and the hereafter. In other words, this concept is an exclusive terminology and consists of several balance values. In general, this concept influences the life of a Muslim and all humans.

Islamic moderation becomes a Muslim identity because everything brought by Islam is part of religion. The principle of thinking balance is to have a kufu understanding of Islam, and it becomes the basis of belief in life based on sharia, the paradigm of knowledge, various deeds, worship style and relationships that transform the culture and character of individuals, whether in inter-social

${ }^{4}$ Islam, Tazul\&Khatun, Amina. 2015. “Islamic Moderation In Perspectives: A Comparison Between Oriental and Occidental Scholarships". International Journal of Nusantara Islam.Vol. 3, No. 2 2015.h.71

5Islam, Tazul\&Khatun, Amina. 2015. “Islamic Moderation In Perspectives: A Comparison Between Oriental and Occidental Scholarships". International Journal of Nusantara Islam.Vol. 3, No. 2 2015.h 72 
agreements, political gatherings, religious doctrines and religious realities, community and national development. ${ }^{6}$

\section{Islamic philanthropy}

The word 'philanthropy' possesses the meaning 'compassion from human'. Philanthropy is an act in which someone provides assistance to others in order to help or improve their quality of life without expecting return or personal interest

Islamic philanthropy provides benefits for public interest which has several sectors and actors both from the private sector and from the government to reciprocally cooperate and develop individual units for their own goals. There are several categories in Islamic philanthropy, such as: zakat, sodaqah, infaq, hibah, and wakaf. Recently, the Islamic philanthropy continues to experience a significant development such as the potential amount of zakat in Indonesia based on research conducted by BAZNAS in 2015 amounted to 286 trillion. ${ }^{7}$

The definition of philanthropy comes from the Greek language "philanthropy" which means compassion and humans. In extended interpretation, the conceptualization of philanthropy is the practice of giving, serving and associating voluntarily to help others. Helmut $\mathrm{K}$. Anheier and Diana Laet 8 mention the approaches used in philanthropy in modern society, namely: (1) charity approach, this approach has a tendency towards occurring social problems, so the perception is relatively temporary; (2) Scientific approach, this approach aims to solve social problems from a scientific point of view. This approach often does not work because it focuses on educational analysis and research alone. Thus, the ability to see the duration, costs, and complexity is often ignored, (3) neo philanthropic (new scientific philanthropy) approach, this approach puts more focused on the process not on the roles, and has less attention to the values of philanthropic institutions and the distinction from other philanthropic institutions.

\section{The mosque management in Jogokariyan}

The mosque is a strategic place of Muslims for ritual, social, scientific and economic purposes as it was practiced during the time of the Prophet (Nurjamilah, 2017). In this place, all people from various social backgrounds, professions and others can mingle for those purposes. ${ }^{9}$

According to No. DJ.II / 802, Decree of the Directorate General of Islamic Community Guidance (Ditjen BIMAS), 2014 Bimas Islam (2014), mosque management includes three aspects, namely idarah (management), imarah (flourish) and ri'ayah (maintenance). Those three things must be implemented by the mosque takmir (administrator) in developing the mosque.

According to data from the Indonesian Mosque Council, the number has reached 290,0000 mosques and 550,000 mushallas. In 2012, the Indonesian

6Bakir, Muhammadul\& Othman, Khatijah. 2017. “Wasatiyyah (Islamic Moderation): A Conceptual Analysis From Islamic Knowledge Management Perspective". Journal Of Islamic Thought And Civilization.Vol. 7, No. 1 2017h. 14-15).

7Fauzia, Amelia. 2017. “Islamic Philanthropy In Indonesia: Modernization, Islamization, And Social Justice". Journal AktuelleSüdostasienforschung Current Research On Southeast Asia: ASEAS. Vol. 10, No. 2 2017.h.22

${ }^{8}$ Anheier and Diana Laet (2006)

${ }^{9}$ Rukmana D.W, Nana Masjid danDakwah, Al-Mawardi Prima, Jakarta, 2002. h. 3. 
Ministry of Religious Affairs states that the number of mosques and mushallas in Indonesia almost reached 900,000.10 That excessive number will result ineffective output if they are not managed properly. Therefore, mosque management needs to be modern and professional.

Among those mosques, Jogokariyan mosque is the one awarded by the Ministry of Religious Affairs on 12 August 2016, as a pilot mosque in national level.

Azzam and Muhyani mention that the management of Jogokariyan mosque distributes $70 \%$ for social aspect and $30 \%$ for ritual aspect. 11

\section{Discussion}

Since 2008, many mosques in Yogyakarta are open at prayer time, and respectively close right after. The mosque is always locked up for keeping cleanliness from the dirt and avoiding theft of mosque properties, such as loudspeakers, charity boxes and etc. However, in the past 10 years, the atmosphere has been replaced by excellent service to community. ${ }^{12}$

One of the mosques having an excellent management is Jogokariyan mosque located in Jogokariyan, Mantrijeron, Yogyakarta city. Jogokariyan Mosque is well recognised mosque by the people in Yogyakarta and Indonesia. An aspect that interest more community to come is the effective and efficient management to flourish the mosque.

The initial establishment of Jogokariyan mosque was in 1966, and the inauguration was in 1967 by the Chairman of PDM (Muhammadiyah Regional Leadership) of Yogyakarta. At that time, Jogokariyan mosque was like common mosques. After that, there was regeneration of takmir (administrator) management in 1999, and they were the second generation since the construction of Jogokariyan mosque. The head of takmir is Ustadz M Jazir who has bright ideas in flourishing the mosque. He changed all the previous mosque management systems into a good system in terms of the strategy in flourishing the mosque. ${ }^{13}$

Jazir did the transformation because he realised that the meaning of the word 'takmir' was to flourish. One of the manifestations of 'to flourish', the mosque takmir must have a database of all the village community, so they find out the number of people praying at the mosque. In this case, one of the main keys is to determine the standard of flourish. We must have clear narratives of how the mosque will be such as the number of worshiper during five time prayers. It must be measured authentically. One way to empower a mosque is to

10Jalil, Jasman, Pendidikan Karakter: Implementasi oleh Guru, Kurikulum, Pemerintah dan Sumber DayaPendidikan, 2018.,h.124

${ }^{11}$ Azzama, Abdulloh dan Muhyani, "Manajemen Masjid Jogokariyan Yogyakarta sebagai Pusat Kegiatan Masyarakat", Komunika: Journal of Communication Science and Islamic Da'wah, Volume 3 (1), 2019. H. 197-205

12Jaya, Indra Pajar Hatma. "Trickle Down Efeck dan Perubahan Wajah Masjid Di Yogyakarta". JurnalInferensi. Vol. 12, No. 1 Juni 2018.h.3

13Wawancara dengan Jazir, selaku pengurus masjid Jogokariyan, pada tanggal, $05 / 29 / 2019)$ 
involve the community to flourish the mosque in certain activities. Therefore, there will be mobilization between the community and the mosque itself ${ }^{14}$.

The thing that makes many people proud and amazed at Jogokariyan mosque is that worshipers at every prayer time are always full, especially in the morning prayer. When the midday prayer, the village mosques in other places contains only a few people. Often the first line is not full. Such condition is in contrast to Jogokariyan mosque. The dawn prayer is always full like Friday prayers or Eid prayer. Surely, to achieve such condition, it requires more time and fully effort from takmirJogokariyan mosque.

Jogokariyan Mosque received an award from the Ministry of Religious Affairs of the Republic of Indonesia (KEMENAG RI) in 2016, as an idarah mosque or a national pilot mosque. The award was given on the basis of the achievement of Jogokariyan mosque to transform abangan community into santri community village. In addition, the Jogokariyan mosque became a reference for the development management of mosques around Yogyakarta. Another reason is because Jogokariyan Mosque successfully held RamadhanJogokariyan Village (Kampung Ramadhan Jogokariyan) in 2005. Those achievements made Jogokariyan Mosque famous in all parts of Indonesia due to its bright ideas in prospering the mosque.

\section{The implementation model of Islamic moderation in Jogokariyan a). religion leader is a nation leader}

The Islamic moderation developed by the Jogokariyan mosque is unique. If many people have been more likely to view pesantren(Islamic boarding) as a centre of learning that creates Islamic leaders throughout history, Jogokariyan mosque has different view. According to Jazir, 15Islamic leadership from the product of pesantren has not succeeded of being accepted by all community. In contrast to the Islamic leadership from the product of mosque, if it is successfully created, it will certainly embrace all members of community around the mosque whatever their group or community they may have. One of the reasons is that pesantren habituate the daily chores into homogeneous community. While mosque leaders are leaders who are accustomed to living in different communities (heterogeneous), so they are accustomed to be wise and moderate in deciding on a problem.

Jazir as a figure of the mosque administrator is active in the mosque and the head of RW around Jogokariyan mosque. Many local residents convey their affairs or aspirations at the mosque office. This is what Jazir perceived as the environment to bring about more popular Muslim leadership compared to pesantren education ${ }^{16}$.

However, the more positions in the community are not recommended. Jogokariyan Mosque has principles that cannot be intervened by anyone. It has to be an independent mosque, stay away from the influence of any party. As stated by Jazir, as the head of Syuro assembly of Jogokariyan mosque, the mosque was

14Wawancara dengan Jazir, selaku pengurus masjid Jogokariyan, pada tanggal, 05/29/2019).

15Wawancara dengan Jazir, selaku pengurus masjid Jogokariyan, pada tanggal, (05/29/2019),

16Wawancara dengan Jazir, selaku pengurus masjid Jogokariyan, pada tanggal, 05/28/2019 
supposed to be independent, no party could control the mosque, even though it was the village government. Even in the organisation structure of the mosque, no one works in a government institution because it will make the mosque unable to develop. Basically they are afraid of their superiors, so there will be many obstacles in the future when a government official interferes in mosque affairs. ${ }^{17}$

\section{b). Facilities for all community level}

Jaya (2018: 3) concludes that many mosques in Yogyakarta are open 24 hours. In addition, there is a mosque that provides facilities for worshipers, both travelers and local residents in the form of free drinking water, food, beds, internet connections and other facilities for free of charge. Haryo P $(05 / 28 / 2019)$ said that all citizens have equal rights in flourishing the mosque. In this sense, the equality of rights was re-emphasized by Jazir to be properly used. If the mosque functions for worship (group prayer), and the number of people in the prayer does not increase or even gets lessen, it means that takmir fails to flourish the mosque. 18

Likewise scientific activities, many elements or groups of Muslims are facilitated to hold events for their communities, without exception. The only condition is that they are not allowed to mock other groups ${ }^{19}$

The various facilities invite many levels of community take part in the activities agenda in Jogokariyan mosque. Jogokariyan Mosque has its own magnetism to be well known nationally.

Zaid $^{20}$ as one of the visitors from Jakarta said that the attraction to visit Jogokariyan mosque was to i'tikaf (stay in the mosque to remember God) during the holy month of Ramadan. As for Samsul21, the management system of infaqwith the model of zero balance is still rarely applied in other mosques. Yudha, as one of the visitors of Jogokariyan mosque said that the attraction of the Jogokariyan mosque was on the regular Islamic activities, such as talk and lectures by national ustadz such as ArifinIlham (late). This is similar to what Bambang said, one of the residents around Jogokariyan mosque. Takmirmosque often invites international religious to give lectures and lead the prayers in Jogokariyan mosque. ${ }^{22}$ Meanwhile, Andre, one of the visitors, said that his interest to visit Jogokariyan mosque is due to the fund management distributed evenly to the entire community both the poor and the sufficient. It is also because there is a rice ATM specifically intended for the poor. ${ }^{23}$

\footnotetext{
17Wawancara dengan Jazir , selaku pengurus masjid Jogokariyan, pada tanggal, 05/28/2019)

18Wawancara dengan Jazir, selaku pengurus masjid Jogokariyan, pada tanggal, 05/28/2019).

${ }^{19}$ Wawancara dengan Jazir, selaku pengurus masjid Jogokariyan, pada tanggal, 05/29/2019).

20Wawancara dengan Zaid, selaku pengunjung non warga sekitar masjid Jogokariyan, padatanggal 29/5/2019. $29 / 5 / 2019$
22Wawancara dengan Bambang, selaku wargasekitar masjid Jogokariyan, pada tanggal 29/5/2019.
${ }^{23}$ Wawancara dengan Samsul, selaku pengunjung sekitar masjid Jogokariyan, pada tanggal

${ }^{21}$ Wawancara dengan Samsul, selaku pengunjung sekitar masjid Jogokariyan, pada tanggal $29 / 5 / 2019$.
} 


\section{Philanthropy fund for social need and economy empowerment}

Sources of mosque cash flow are derived from Islamic philanthropic funds such as zakat, infak, sedekah, wakaf, hibah.These funds are used for religious, social, economic and other purposes. For example, Haryo P is a doctor who offers his expertise in health and medicine to examine the sick community. Responding this offer, the mosque takmir establishes polyclinic. In addition, there are also those who devote time to clean the bathroom, so every bathroom has a man in charge for the cleanliness and comfort. The other form of donation can be ideas and materials. ${ }^{24}$

One of the uniqueness of the Jogokariyan Mosque, which captivates the general public, is that the mosque will replace all the lost items in the area such as sandals, shoes, bicycles and even motorbikes. They are replaced according to those items which are lost and bought in new condition. Jogokariyan Mosque is also equipped with CCTV in various areas of the mosque..$^{25}$

\section{Building sense of belonging toward Jogokariyan mosque}

Jazir proposes the concept of zero balance on mosque finances and encourage the surrounding community to participate in flourishing the mosque based on their capabilities. At the beginning of infaq as one of the main funds for the mosque, in 1999 the total is Rp 8,640,000 per year, or Rp 180,000 per Friday was collected. A year later in the period 2000-2004 with the movement of an independent infaq, the collected fund reaches Rp. 43.2 million a year. For the period of 2004-2006, Rp. 95,720,000 was collected. Moreover, during 2006-2008, the fund collected Rp. 225,000,000. For the period of 2008-2010, the funds achieve Rp. 354,280,000, and lately in 2018 the funds have been collected approximately 3.2 billion rupiah. ${ }^{26}$

The efforts to encourage the community are what ultimately make the community have a sense of belonging to the mosque. Moreover, the mosque administrators can also convince worshipper to be an "independent community".

That case can occur because Jogokariyan mosque has a great management in fostering the mosque. Jogokariyan Mosque has 30 divisions for specific fields such as the youth, the alms giving, da'wah and etc.

Rosyidi, ${ }^{27}$ one of the takmir staff of Jogokariyan mosque, said that basically this mosque belongs to community. Therefore, anyone who wants to give support is invited to work together. So that takmir is not the only person playing the roles.

\section{The development of batik cap (udheng) as the icon of Javanese society}

KampungRamadhanJogokariyan (KRJ) becomes an icon that makes the community open in making changes to the mosque. It is not only on the issue of $28 / 5 / 2019$.

24Wawancara dengan Haryo $\mathrm{P}$, selaku pengunjung sekitar masjid Jogokariyan, pada tanggal

25Jaya, Indra Pajar Hatma. 2018. “Trickle Down Efeck dan Perubahan Wajah Masjid Di Yogyakarta". Jurnal Inferensi. Vol. 12, No. 1 Juni 2018.h. 8

${ }^{26}$ Wawancara dengan Jazir , selaku pengurus masjid Jogokariyan, pada tanggal, 05/29/2019).

27Wawancara dengan Rosyidi, selaku pengurus takmir masjid Jogokariyan, pada tanggal $28 / 5 / 2019$. 
the mosque building but also its management. Besides, there are also rewards for community members to get involved in fostering the mosque. For example, the mosque gives free Umrah (visit to Kabah) to any residents who are diligent in offering jamaah (group) prayers at the mosque. On the other hand, the mosque has facilities such as rooms with the quality of 3 star hotels to accommodate mosque guests with affordable and free of charge for people who run out of money / poor. In addition, Jogokariyan mosque has VIP facilities, such as air conditioning, polyclinics, cooperatives, and finger print presence devices.

Since 2005, Jogokariyan mosque has succeeded in managing and developing the economy of the mosque-based community by the existence of the Jogokariyan village market every Ramadan. Every year, the number of people trading in RamadhanJogokariyan village continues to increase. In Ramadhan Kampong Market $1441 \mathrm{H}$, there are approximately 650 outlets / stalls, both those which register to the committee or that who do not. In this case, a trader does not have to register to the committee, as long as they do not occupy the place of another trader. Therefore, it will not create a problem. The function of the registration of trade stands is to map the position of any place that is already occupied by traders. This fact shows that the mosque is able to provide employment for Jogokariyan community and society in general. ${ }^{28}$ The success of RamadhanJogokariyan village market as a means of developing the mosquebased sharia economy is influenced by several factors, both internally and externally.

Many factors support the advancement of shariah economy around Jogokariyan mosque. For example the Ramadan market, the merchant can get loan from the mosque for initial capital. After the market is close, they return the money to the mosque. This system is commonly referred to qard al hasan ${ }^{29}$. About $17 \%$ of them can open a kiosk / shop to trade. This is one of the visions and missions of the mosque to encourage individual to be economically independent by developing their business. If there is no capital, the mosque will lends some money for trader. ${ }^{30}$ That system grows people spirit to trade, and not to be afraid of loan from the mosque due to the absence of riba (interest) as explained above.

Another factor on the development of syariah economics is the character of transparency of all parties. Thus, there is no suspicion of anyone. In addition, the use of technological facilities through social media strongly supports the advancement of the economy in Jogokariyan society. Many people know about Jogokariyan from social media. The more people recognize Jogokariyan, the more economic development Jogokariyan community will have.

One of real proofs is Jardiyanto, a cap craftsman with batik patchwork material. Jardiyanto was just an unemployed person. By his hobby in making unique caps, the mosque provides assistance to Jardiyanto, including promotion and provision of initial capital. Nowadays, Jardiyanto's product has become a typical merchant for Jogokariyan mosque, which is a batik patchwork cap. At the beginning of production, not many people were interested, so the turnover was

${ }^{28}$ Wawancara dengan Jazir, selaku pengurus masjid Jogokariyan, pada tanggal ,

${ }^{29}$ Wawancara dengan Sri, selaku pedagang kaki lima sekitar masjid Jogokariyan, pada tanggal 29/5/2019

${ }^{30}$ Wawancara dengan Jazir, selaku pengurus masjid Jogokariyan, pada tanggal, 29/5/2019) 
still small. Then Jardiyanto marketed his products through RamadhanJogokariyan village, also promoted by the takmir of Jogokariyan mosque. In Ramadhan, Jardiyanto's turnover reaches 40 pcs a day from online transaction and 20 pcs from offline one. Meanwhile, on a normal day, the turnover is around 30 pcs. This patchwork batik cap has also been exported to Malaysia in the amount of around 1500 pcs. ${ }^{31}$

In another context, by the existence of this KampungRamadhanJogokariyan (RamadhanJogokariyan village), all stalls are required to register to takmir of Jogokariyan mosque although the road belongs to government. There is no actual correlation between the mosque and the government. However, the government satisfies with the existence of this Ramadan Village because the market contributes something the local residents. In addition, the event opens job vacancies for local people that the government has not been able to do so.

The discussion in the Regional Government, by the Governor, the Deputy Governor and the entire staff concludes that national or regional development budget (APBN / APBD) cannot reduce poverty. The reason lays on the small amount of the budget. Therefore, an emerging solution is by empowering communities to alleviate poverty. One example is Jogokariyan mosque which develops communities, so that employment can be created.

\section{Conclusion}

The implementation of moderate Islamic model implemented by the administrators of Jogokariyan mosque has shown significant process and results. Community involvement in all mosque empowerment agendas is optimized in such a way that the outputs of activities related to worship, social, economic, health and others can be optimally carried out.

However, the model of Islamic moderation exemplified by Jogokariyan has inspired many mosques throughout Indonesia. Some of them have even surpassed Jogokariyan mosque in several activities

The pattern of manifestation from theoretical stage to application for other mosques is certainly not as easy as turning a hand. Disputes between young people and the elderly, or disputes between some takmir and others, or disputes between santri (student at traditional Muslim school) and abangan(one who does not adhere strictly to the precepts of religion), often become problems that must be resolved before leading to the optimization of the mosque's role. Future research can be focused on overcoming these issues. Wallahua'lambishshawab

\section{Bibliography}

Azzama, Abdulloh dan Muhyani, "Manajemen Masjid Jogokariyan Yogyakarta sebagai Pusat Kegiatan Masyarakat", Komunika: Journal of Communication Science and Islamic Da'wah, Volume 3 (1), 2019.

Bakir, Muhammadul \& Othman, Khatijah. 2017. "Wasatiyyah (Islamic Moderation): A Conceptual Analysis From Islamic Knowledge

31Wawancara dengan Jardiyanto, selaku pengusaha peci batik sekitar masjid Jogokariyan, pada tanggal 29/5/2019. 
Management Perspective". Journal Of Islamic Thought And Civilization.Vol. 7, No. 12017.

Fauzia, Amelia. 2017. "Islamic Philanthropy In Indonesia: Modernization, Islamization, And Social Justice". Journal AktuelleSüdostasienforschung Current Research On Southeast Asia: ASEAS. Vol. 10, No. 2017.

Helmut K. Anheier \& Diana Leat, Creative Philanthropy Towards a New Philanthropy for the Twenty-First Century, Newyork: Routledge, 2006.

Http:/ / nasional.kompas.com/read/2008/09/30/00185540/potensi.zakat.triliuna n.rupiah, diambil pada tanggal 18/4/2017.

Islam, Tazul \& Khatun, Amina. 2015. "Islamic Moderation In Perspectives: A Comparison Between Oriental and Occidental Scholarships". International Journal of Nusantara Islam.Vol. 3, No. 22015.

Jalil, Jasman, Pendidikan Karakter: Implementasioleh Guru, Kurikulum, Pemerintahdan Sumber Daya Pendidikan, 2018.

Jaya, Indra Pajar Hatma. "Trickle Down Efeck dan Perubahan Wajah Masjid Di Yogyakarta". Jurnal Inferensi. Vol. 12, No. 1 Juni 2018.

Keputusan Ditjen BIMAS Islam, 2014 Bimas Islam.

Muhtada D. 2014. "Islamic Philanthropy and The Third Sector: The Portrait of Zakat Organizations in Indonesia". Journal Islamika Indonesiana.Vol. 1, No. 1 2014.

Rukmana D.W, Nana Masjid dan Dakwah, Al-Mawardi Prima, Jakarta, 2002. Wawancaradengan Andre, selaku pengunjung sekitar masjid Jogokariyan, pada tanggal 29/5/2019.

Wawancara dengan Bambang, selaku warga sekitar masjid Jogokariyan, pada tanggal 29/5/2019.

Wawancara dengan Haryo P, selaku pengunjung sekitar masjid Jogokariyan, pada tanggal 28/5/2019

Wawancara dengan Jardiyanto, selaku pengusaha peci batik sekitar masjid Jogokariyan, pada tanggal 29/5/2019.

Wawancara dengan Rosyidi, selaku pengurus takmir masjid Jogokariyan, pada tanggal 28/5/2019.

Wawancara dengan Samsul, selaku pengunjung sekitar masjid Jogokariyan, pada tanggal 29/5/2019.

Wawancara dengan Sri, selaku pedagang kaki lima sekitar masjid Jogokariyan, pada tanggal 29/5/2019.

Wawancara dengan Zaid, selaku pengunjung non warga sekitar masjid Jogokariyan, pada tanggal 29/5/2019. 